\title{
Salinity and temperature effects on the growth and chlorophyll-a content of some planktonic algae
}

\author{
Teresa Cristina Siqueira SIGAUD \& Elizabeth AIDAR
}

Instituto Oceanográfico da Universidade de São Paulo

(Caixa Postal 9075, 01065-970 São Paulo, SP, Brasil)

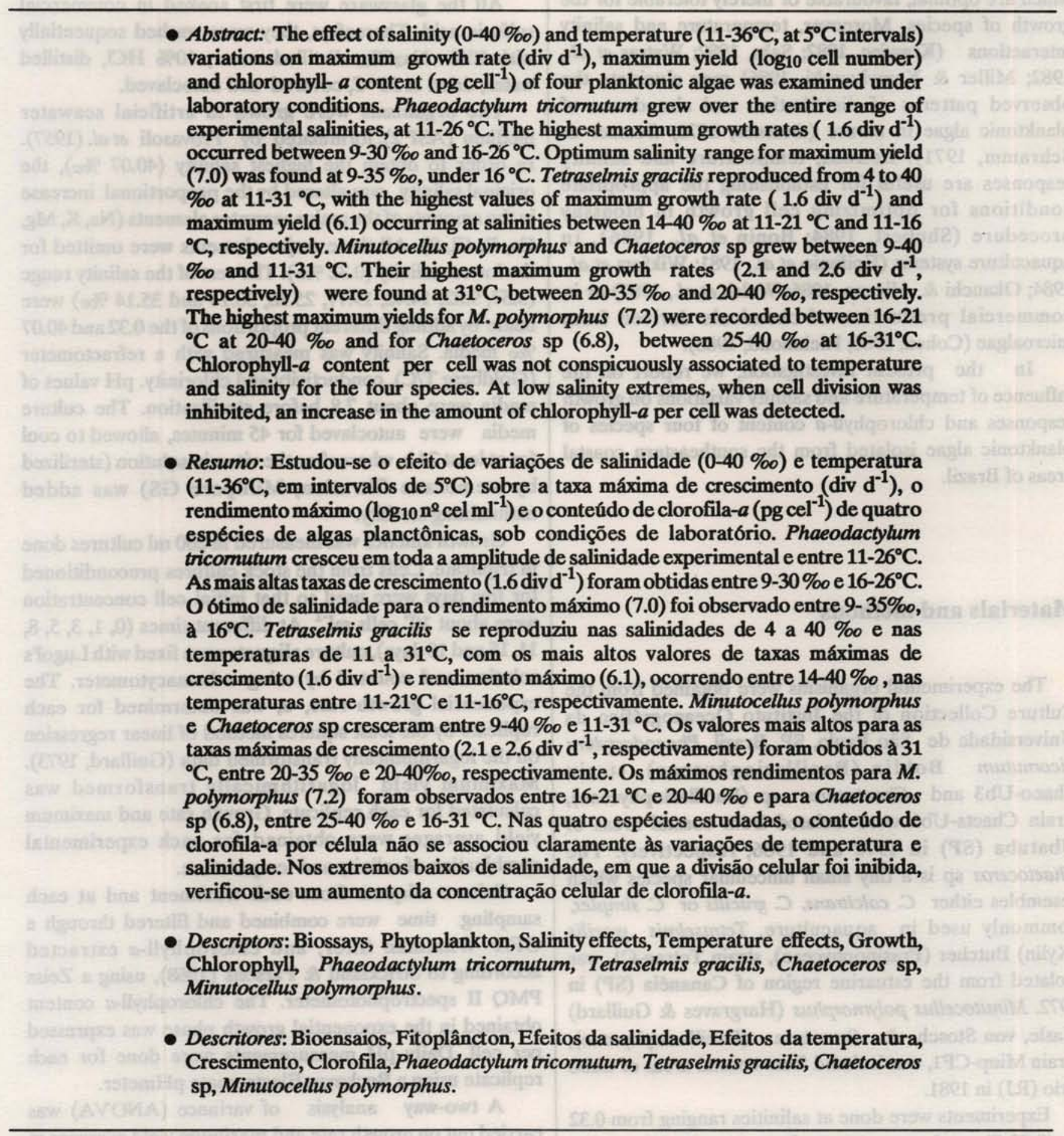

Contr. no. 755 do Inst. oceanogr. da Usp. 


\section{Introduction}

A study of the physiological responses of microalgae in relation to variations in salinity (Shimura et al., 1979; Brown, 1982; Brand, 1984; Fabregas et al., 1984, 1985, 1987; Tsuruta et al., 1985; Rendall \& Wilkinson, 1986) and temperature (Verity, 1981; Redalje \& Laws, 1983; Baars, 1988a,b) can reveal some differences on their adaptability to the environment. Ecophysiological studies are helpful in determining environmental conditions which are optimal, favourable or merely tolerable for the growth of species. Moreover, temperature and salinity interactions (Krawiec, 1982; Saks, 1982; Watras et al., 1982; Miller \& Kamykowski, 1986) may elucidate the observed patterns of distribution and abundance of planktonic algae in nature (Gessner, 1970; Gessner \& Schramm, 1971). Besides, temperature and salinity responses are useful for establishing the appropriate conditions for optimizing cell growth in bioassay procedure (Shubert, 1984; Bonin et al., 1986), in aquaculture systems (Epifanio et al., 1981; Wikfors et al., 1984; Okauchi \& Hirano, 1986; Walsh et al., 1987) or in commercial production of chemicals derived from microalgae (Cohen, 1986; Richmond, 1986).

In the present investigation, we report on the influence of temperature and salinity variations on growth responses and chlorophyll- $a$ content of four species of planktonic algae isolated from the southeastern coastal areas of Brazil.

\section{Materials and methods}

The experimental organisms were obtained from the Culture Collection of the Instituto Oceanografico da Universidade de São Paulo, SP, Brazil. Phaeodactylum tricomutum Bohlin (Bacillariophyceae), strain Phaeo-Ub3 and Chaetoceros sp (Bacillariophyceae), strain Chaets-Ub1 were isolated from coastal areas of Ubatuba (SP) in 1972 and 1986, respectively. The Chaetoceros $\mathrm{sp}$ is a tiny small unicellular species which resembles either $C$. calcitrans, $C$. gracilis or $C$. simplex, commonly used in aquaculture. Tetraselmis gracilis (Kylin) Butcher (Prasinophyceae), strain Tetrag-C1, was isolated from the estuarine region of Cananeia (SP) in 1972. Minutocellus polymorphus (Hargraves \& Guillard) Hasle, von Stosch \& Syvertsen (Bacillariophyceae), strain Minp-CF1, was isolated from coastal areas of Cabo Frio (RJ) in 1981.

Experiments were done at salinities ranging from 0.32 to $40.07 \%$ and temperatures from 11 to $36^{\circ} \mathrm{C}$, at $5^{\circ} \mathrm{C}$ intervals. These were done in batch cultures. Stock cultures at these salinities and temperatures were established through stepwise subculturing, from an initial stock at $30 \%$ salinity and $21^{\circ} \mathrm{C}$ temperature. The cultures were not bacteria free and grown in $300-\mathrm{ml}$ borosilicate Erlenmeyer flasks, in controlled temperature and light incubators. The light intensity was $125 \mu \mathrm{E} \mathrm{m}^{-2} \mathrm{~s}^{-1}$, which was provided by fluorescent lamps (TLD 15w/54). Light was measured with a Lambda Instruments LI-190S quantum sensor and LI-185A quantum meter. A 12:12 light-dark regime was chosen.

All the glassware were first soaked in commercial sulfuric acid. Thereafter, they were washed sequentially with $10 \% \mathrm{Na}_{2} \mathrm{CO}_{3}$, distilled water, $10 \% \mathrm{HCl}$, distilled water, dried at $50^{\circ} \mathrm{C}$, covered and autoclaved.

The organisms were grown in artificial seawater medium (ASP 2), formulated by Provasoli et al. (1957). In order to obtain the highest salinity $(\mathbf{4 0 . 0 7} \%$ ) , the original salinity was altered by the proportional increase in the amounts of the major seawater elements $(\mathrm{Na}, \mathrm{K}, \mathrm{Mg}$, $\mathrm{Ca}, \mathrm{B}, \mathrm{Cl}, \mathrm{S})$. All these major elements were omitted for the lowest salinity $(0.32 \%)$. The rest of the salinity range $(3.57,9.02,14.42,19.77,25.18,30.14$ and $35.14 \%$ ) were made by adding different proportions of the 0.32 and 40.07 $\% o$ media. Salinity was measured with a refractometer (Goldberg T/C), conductivity and chlorinity. $\mathrm{pH}$ values of media were about 7.8 before sterilization. The culture media were autoclaved for $\mathbf{4 5}$ minutes, allowed to cool for at least $24 \mathrm{~h}$, whereafter the vitamin solution (sterilized by membrane filtration, Millipore GS) was added maintaining sterility.

Growth kinetics was measured in $200 \mathrm{ml}$ cultures done in triplicate. Cells from the stock cultures preconditioned for five days were used so that initial cell concentration were about $10^{4}$ cells ml-1 ${ }^{-1}$. At different times $(0,1,3,5,8$, 11,15 and 18 days), culture aliquots were fixed with Lugol's solution and counted by using a hemacytometer. The exponential growth rate, $u$, was determined for each replicate by the least squares method of linear regression on the logarithmically transformed data (Guillard, 1973). Maximum yield logarithmically transformed was calculated for each replicate. Growth rate and maximum yield averages were obtained for each experimental combination of salinity and temperature.

Culture aliquots from each treatment and at each sampling time were combined and filtered through a GF/F Whatman filter, and chlorophyll- $a$ extracted according to Strickland \& Parsons (1968), using a Zeiss PMQ II spectrophotometer. The chlorophyll- $a$ content obtained in the exponential growth phase was expressed per cell. Daily pH measurements were done for each replicate using a Beckman Electromate pHmeter.

A two-way analysis of variance (ANOVA) was carried out on growth rate and maximum yield averages in 
order to test temperature and salinity effects. Differences between averages were tested for statistical significance $(P>0,05)$ with the Tukey method of multiple comparisons (Neter et al., 1990). The results of chlorophyll- $a$ content per cell at the exponential growth phase were subjected to the Tukey test for additivity (Neter et al., op. cit.) to examine whether or not the two experimental factors interact. In case of a non-interactive model, a two-way analysis of variance (ANOVA) was applied, followed by the Tukey multiple comparison procedure. If the model was interactive, the Tukey method was employed directly, considering the pure error

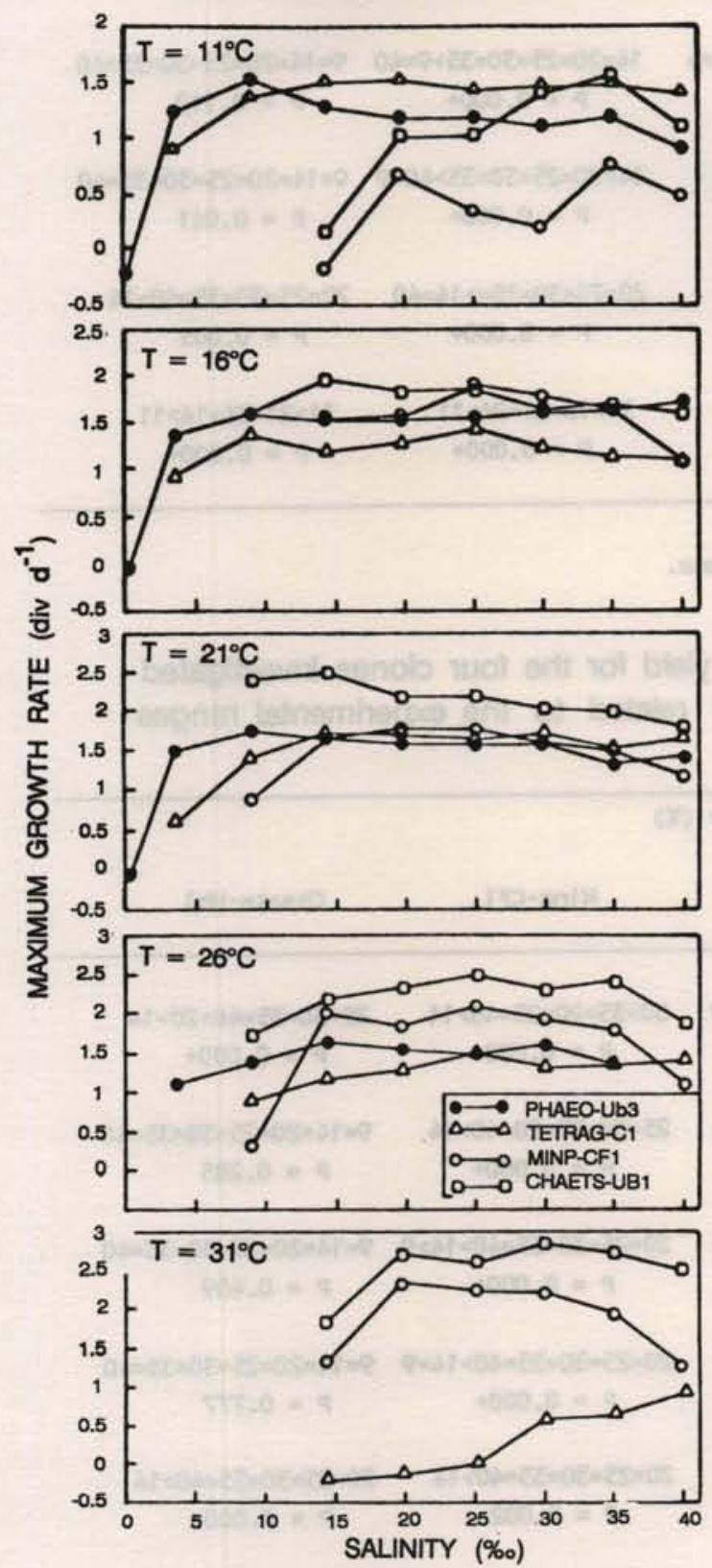

Fig. 1. Maximum growth rate $\left(\operatorname{div} d^{-1}\right)$ of Phaeodactylum tricornutum (Phaeo-Ub3), Tetraselmis gracilis (Tetrag-C1), Minutocellus polymorphus (Minp-CF1) and Chaetoceros sp (Chaets-Ub1) as a function of salinity and temperature. mean square, which represents the random variability of the error, excluding the interaction effects.

\section{Results}

The average maximum growth rates (Fig. 1) and maximum yields (Fig. 2) were plotted against salinity for each temperature and test species. The outcome of the statistical calculations are given in Tables 1-2. The coefficients of variation for the replicates were generally low (C.V. $<10 \%$ ), except at the extremes of salinity and temperature.
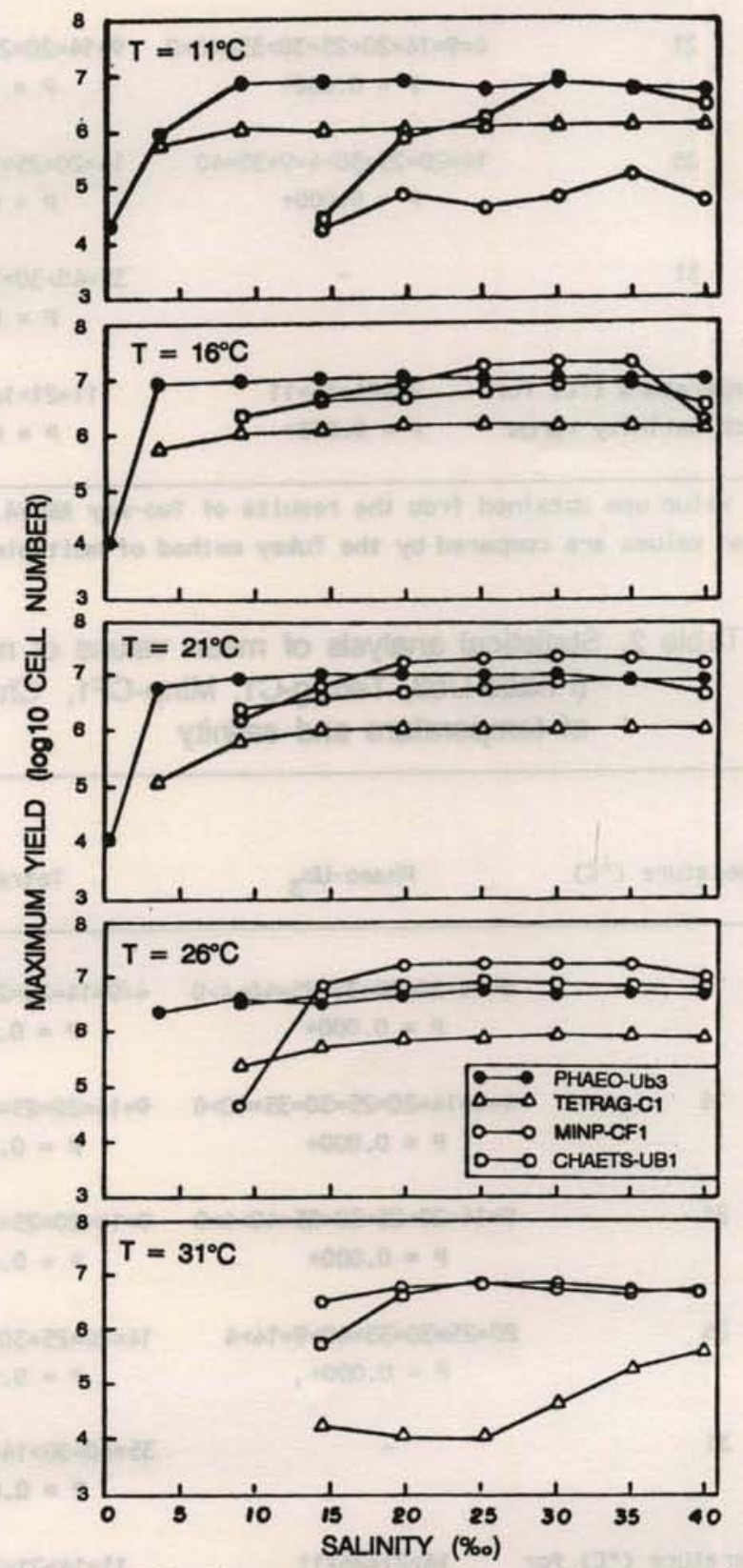

Fig. 2. Maximum yield ( $\log _{10}$ cell number) of Phaeodactylum tricornutum (Phaeo-Ub3), Tetraselmis gracilis (Tetrag-C1), Minutocellus polymorphus (Minp-CF1) and Chaetoceros sp (Chaets- Ub1) as a function of salinity and temperature. 
Table 1. Statistical analysis of mean values of maximum growth rate for the four clones investigated (Phaeo-Ub3, Tetrag-C1, Minp-CF1, Chaets-Ub1), related to the experimental ranges of temperature and salinity

Sal inity (X)

$\begin{array}{lllll}\text { Temperature }\left({ }^{\circ} \mathrm{C}\right) & \text { Phaeo- }-\mathrm{b}_{3} & \text { Tetrag-C1 } & \text { Minp-CF1 } & \text { Chaets-Ub1 }\end{array}$

11

16

21

26

31

Temperature $\left({ }^{\circ} \mathrm{C}\right)$ for each salinity range
$9=14>4=20=25=30=35=40>0$

$$
P=0.000+
$$

$4=9=14=20=25=30=35=40>0$

$P=0.000+$

$4=9=14=20=25=30>35=40>0$

$$
P=0.000+
$$

$14=20=25=30>4=9=35=40$

$P=0.000+$

$P$ value was obtained from the results of Two-way ANOVA.

Mean values are compared by the Tukey method of mult iple comparisons.

Table 2. Statistical analysis of mean values of maximum yield for the four clones investigated (Phaeo-Ub3, Tetrag-C1, Minp-CF1, Chaets-Ub1) related to the experimental ranges of temperature and salinity

\section{Salinity (\%)}

11

16

21

26

31

Temperature $\left({ }^{\circ} \mathrm{C}\right)$ for each salinity range

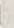

\section{$9=14=20=30=35>25=40>4>0$}

$$
P=0.000+
$$

$4=9=14=20=25=30=35=40>0$

$$
P=0.000+
$$

$9=14=20=25=30=35=40>4>0$

$$
P=0.000+
$$

$20=25=30=35=40>9=14>4$

$$
P=0.000+
$$

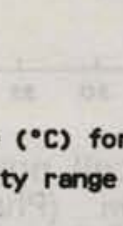

$$
\begin{aligned}
& 16>21=26>11 \\
& P=0.000+
\end{aligned}
$$

$4=9=14=20=25=30=35=40$

$$
P=0.098
$$

$9=14=20=25=30=35=40>4$

$$
P=0.027
$$

$9=14=20=25=30=35=40>4$

$$
P=0.000+
$$

$$
\begin{gathered}
14=20=25=30=35=40>9 \\
P=0.000+ \\
35=40>30>14=20=25 \\
P=0.000+
\end{gathered}
$$

$30>35>20=25=40>14$

$$
P=0.000+
$$

$25=30=35=40>20>14$

$25=30=35>20=40>14$

$$
P=0.000+
$$

$9=14=20=25=30=35=40$

$$
P=0.285
$$

\section{$20=25=30=35=40>14>9 \quad 9=14=20=25=30=35=40$}

$$
P=0.000+\quad P=0.409
$$
$20=25=30=35=40>14>9 \quad 9=14=20=25=30=35=40$

$$
P=0.000+\quad P=0.77
$$

$20=25=30=35=40>14$

$$
P=0.002
$$

\section{$20=25=30=35=40>14$}

$P=0.000+$

$16=21>26=31>11$

$16=21=26=31>11$

$P=0.000+$

$P=0.000+$

$P$ value was obtained from the results of Two-way ANOVA.

Mean values are compared by the Tukey method of multiple comparisons. 
P. tricornutum, growing over the entire range of experimental salinities and $T$. gracilis reproducing between $4-40 \%$ were more euryhaline than $M$. polymorphus and Chaetoceros sp which grew in a salinity range of $9-40 \%$.

The temperature $36^{\circ} \mathrm{C}$ was lethal for the four species. T. gracilis, $M$. polymorphus and Chaetoceros sp, growing between 11 and $31^{\circ} \mathrm{C}$, were more eurythermic than $P$. tricornutum which was unable to survive at $31^{\circ} \mathrm{C}$.

The highest maximum growth rates $\left(1.6 \operatorname{div~d}^{-1}\right)$ for $P$. tricornutum and $T$. gracilis were measured at salinities ranging from 9 to $30 \%$ and 14 to $40 \%$, respectively. For $M$. polymorphus $\left(2.1 \mathrm{div} \mathrm{d}^{-1}\right)$ and Chaetoceros sp $\left(2.6 \mathrm{div} \mathrm{d}^{-1}\right)$ these values were found between $20-35 \%$ and $20-40 \%$, respectively. The optimum temperatures obtained for maximum growth rate were between $16-26^{\circ} \mathrm{C}$ for $P$. tricornutum, between $11-21^{\circ} \mathrm{C}$ for $T$. gracilis, and $31^{\circ} \mathrm{C}$ for $M$. polymorphus and Chaetoceros sp (Fig. 1).

The highest maximum yields ( $\log _{10}$ cell number) were found for $M$. polymorphus (7.2) and $P$. tricornutum (7.0) at salinities between $20-40 \%$ and 9-35\%, respectively. Chaetoceros sp and $T$. gracilis showed their maximum values (6.8 and 6.1, respectively) in media with salinities of $25-40 \%$ and $14-40 \%$, respectively. The optimum temperatures for achieving the highest maximum yields were $16^{\circ} \mathrm{C}$ for P. tricomutum, $11-16^{\circ} \mathrm{C}$ for $T$. gracilis, $16-21^{\circ} \mathrm{C}$ for M. polymorphus and $16-31^{\circ} \mathrm{C}$ for Chaetoceros sp (Fig. 2).

Chlorophyll- $a$ contents per cell against salinity and temperature for each species are shown in Figure 3. The Tukey test for additivity and the two-way analysis of variance showed that temperature and salinity did not have an influence on the chlorophyll- $a$ contents per cell for $P$. tricomutum and T. gracilis.

For both M. polymorphus and Chaetoceros sp the Tukey test for additivity pointed out the existence of a significant interaction between temperature and salinity on chlorophyll- $a$ results. According to the Tukey method of multiple comparisons, certain temperature-salinity combinations $\left(\mathrm{T}=16^{\circ} \mathrm{C}, \mathrm{S}=\right.$ $14 \%$ for $M$. polymorphus and $\mathrm{T}=11^{\circ} \mathrm{C}, \mathrm{S}=14 \%$ for Chaetoceros sp) produced the highest values (Fig. 3). At low salinity extremes, when cell division was inhibited, an increase in the amount of chlorophyll- $a$ per cell was detected for $M$. polymorphus, Chaetoceros sp and P. tricomutum (Fig. 3).

The culture media showed $\mathrm{pH}$ values between 7.3-8.6 for P. tricomutum, 7.6-8.4 for T. gracilis, 7.4-8.3 for $M$. polymorphus and 7.6-8.3 for Chaetoceros sp.
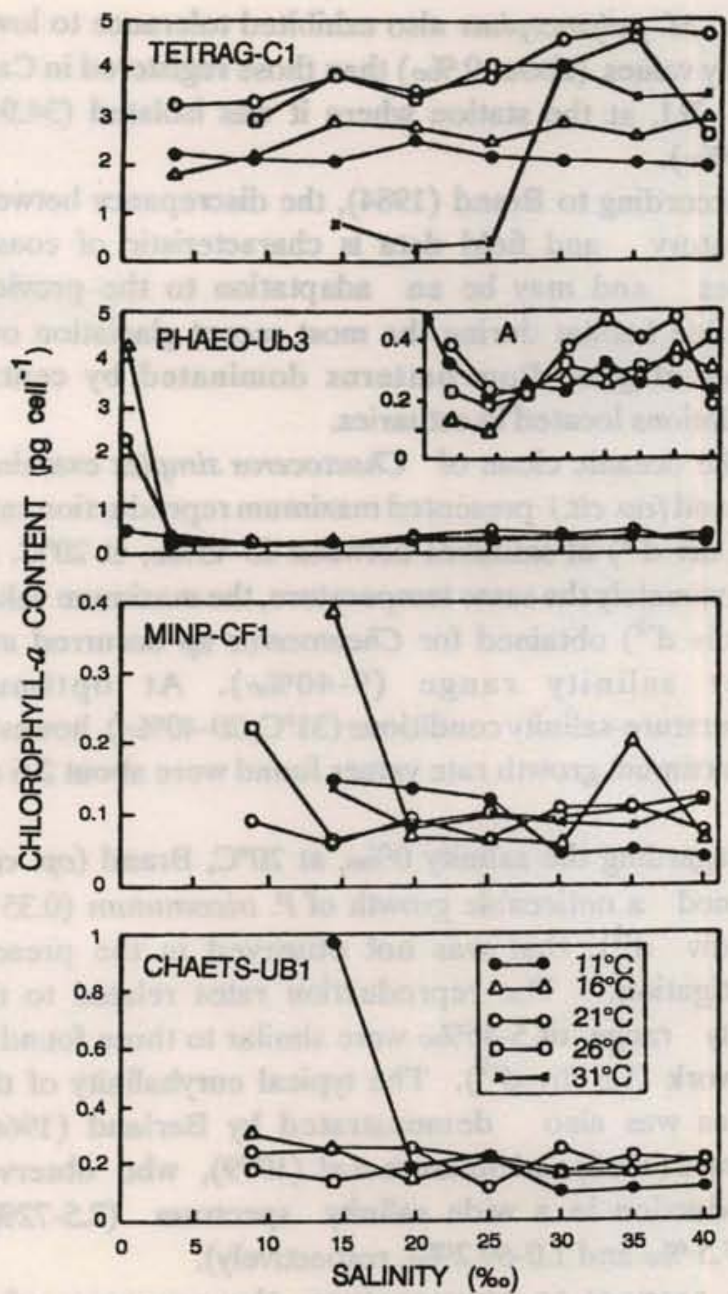

Fig. 3. Chlorophyll- $a$ content (pg cell $\left.{ }^{-1}\right)$ at different temperatures for Tetraselmis gracilis (Tetrag-C1), Phaeodactylum tricornutum (Phaeo-Ub3), Minutocellus polymorphus (Minp-CF1) and Chaetoceros sp (Chaets-Ub1), as a function of salinity. A. Chlorophyll- $a$ data excluding the highest values relative to the salinity of $0.32 \%$.

\section{Discussion}

Natural and cultured microalgae can show good agreement in respect to salinity tolerance (Paasche, 1975; Krawiec, 1982; Saks, 1982; Rendall \& Wilkinson, 1986). Tetraselmis gracilis, a brackish water flagellate, reproducing from 4 to $40 \%$, revealed a salinity growth range compatible with the salinity regimes occurring in Cananéia (from 1 to $35 \%$, according to Aidar-Aragão, 1980), its original habitat. However, P. tricomutum and Chaetoceros sp were able to survive at much lower salinities (about 0 and $9 \%$, respectively) than those found at Ubatuba coastal waters, where the diatoms strains were collected. In this region, salinity is quite constant (34.03-35.53\%o), except for some relatively low values occurring bordering the inner parts of the bays (Teixeira, 
1973). M. polymorphus also exhibited tolerance to lower salinity values (about $9 \%$ ) than those registered in Cabo Frio - RJ, at the station where it was isolated (34.94 $35.80 \%$ ).

According to Brand (1984), the discrepancy between laboratory and field data is characteristic of coastal species and may be an adaptation to the previous estuarine habitat during the most recent glaciation or a reflect of gene flow patterns dominated by central populations located in estuaries.

The oceanic clone of Chaetoceros simplex examined by Brand (op. cit.) presented maximum reproduction rates

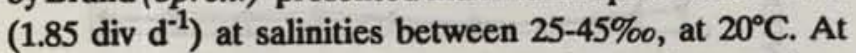
approximately the same temperature, the maximum values (2.1 div $\mathrm{d}^{-1}$ ) obtained for Chaetoceros sp occurred at a wider salinity range $(9-40 \% 0)$. At optimum temperature-salinity conditions $\left(31^{\circ} \mathrm{C} ; 20-40 \% 0\right)$, however, the maximum growth rate values found were about $2.6 \mathrm{div}$ $\mathrm{d}^{-1}$.

Regarding the salinity $0 \%$, at $20^{\circ} \mathrm{C}$, Brand (op. cit.) obtained a noticeable growth of $P$. tricomutum $(0.35$ to $1.24 \mathrm{div} \mathrm{d}^{-1}$ ), that was not observed in the present investigation. The reproduction rates related to the salinity range of $5-45 \%$ were similar to those found in this work (1.6 div $\left.\mathrm{d}^{-1}\right)$. The typical euryhalinity of this species was also demonstrated by Berland (1966), Hayward (1968) and Shimura et al. (1979), who observed reproduction in a wide salinity spectrum $(2.5-72 \%$, 4.4-87.5\%o and 1.0-69.2\%, respectively).

In respect to temperature, the presence of $P$. tricomutum in Ubatuba-SP is associated with $22^{\circ} \mathrm{C}$ (Vieira, 1975). Indeed, this temperature is near the optimum determined for the same clone in relation to a wide spectrum of physiological processes, under laboratory conditions (Vieira, op. cit.; Gaeta, 1985). Based on the results of Vieira (op. cit.) and on those found at the present investigation, the lethal temperature for this isolate is between 27 and $30^{\circ} \mathrm{C} . P$. tricomutum is frequently the dominant species in both enriched laboratory and outdoor mass cultures. Nevertheless, its temperature optimum found in defined laboratory experiments $\left(20^{\circ} \mathrm{C}\right)$ is obscured by the interactions of other environmental factors found outdoors, so that $P$. tricomutum can be dominant outdoors over a wide range of temperature, between $0-25^{\circ} \mathrm{C}$ (Goldman \& Ryther, 1976; Goldman, 1977a; Goldman \& Mann, 1980).

Cell division in $P$. tricomutum is relatively slow, considering its size, i. e., $24 \mathrm{um}$ in length (Bonin et al., 1986). In this study, the maximum value found was 1.84 div $\mathrm{d}^{-1}$, obtained for one of the replicates at $9 \%$ salinity and $11^{\circ} \mathrm{C}$ temperature. The maximum growth rate found

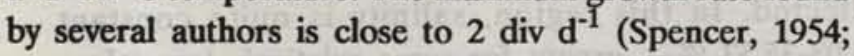
Nelson et al., 1979; Sharp et al., 1979; Gaeta, 1985).
Ben-Amotz \& Gilboa (1980) and Fawley (1984) recorded maximum division rate values of $2.3\left(20^{\circ} \mathrm{C}\right)$ and 2.16 div d$^{-1}$ $\left(23^{\circ} \mathrm{C}\right)$, respectively. However, Subba Rao (1981) mentioned maxima about $1.0 \mathrm{div} \mathrm{d}^{-1}$. In outdoor tanks, the values are even much lower (Raymont \& Adams, 1958).

Clones of $M$. polymorphus (referred as Bellerochea polymorpha), isolated from different environments and studied by Hargraves \& Guillard (1974), showed salinity and temperature tolerance ranges very similar to those obtained in the present work. For the salinity spectrum of $1.2-32 \%$, they observed that this diatom was able to reproduce between $8-32 \%, 12-32 \%$ or $16-32 \%$, with these salinity ranges permitting growth rate estimated as half maximal value or greater. The five clones examined presented a measurable growth from $11^{\circ} \mathrm{C}$ or $15^{\circ} \mathrm{C}$ to $30.5^{\circ} \mathrm{C}$ or $31.5^{\circ} \mathrm{C}$. At these highest temperatures, they exhibited rapid and consistent growth responses. In our clone, however, maximum growth rates at $9 \%$ salinity were equal or lower than half maximal value. It also showed the highest maximum growth rates at $31^{\circ} \mathrm{C}\left(2.1 \mathrm{div} \mathrm{d}^{-1}\right)$, between $20-35 \%$, indicating that its high temperature limit might be still higher, as it was found for the tropical clones previously described.

T. gracilis grew almost over the whole experimental salinity range, with maximum growth rates between $14-40 \%$. As a matter of fact, the genus Tetraselmis has been often cited as specially able to tolerate wide salinity fluctuations, since it grows at almost constant rates in a wide salinity spectrum (McLachlan, 1961; Hellebust, 1976; Fabregas et al., 1984). It was also considered to be an eurythermic organism, developing at environmental temperatures between 5-33 C (Okauchi \& Fukusho, 1984). However, our results showed a weak growth of $T$. gracilis at $31^{\circ} \mathrm{C}$.

Temperature has been considered one of the most important variables affecting algal growth (Eppley, 1972; Raven \& Geider, 1988; Kozitskaya, 1989) and the chemical composition of the marine microalgae (Furnas, 1978; Yoder, 1979; Verity, 1981). The highest cellular contents of nitrogen, carbon and chlorophyll have been found at the extremes of the temperature growth range (Goldman \& Ryther, 1976; Goldman, 1977a,b; Goldman \& Mann, 1980), in continuous cultures. However, as it concerns to the cellular chlorophyll-a content, this behaviour has not been frequently observed because of the diversity of culture techniques and species and also due to the influence of light-dark cycles (Bonin et al., 1986). Several authors have found maximum cellular chlorophyll contents at the most favourable temperature for growth. This pattern was shown for $P$. tricornutum and Nitzschia closterium (Morris \& Glover, 1974), Chaetoceros curvisetum (Furnas, 1978), Skeletonema costatum (Yoder, 1979). For Leptocylindrus danicus, the maximum chlorophyll-a content was related to the 
optimum temperature for the photosynthetic rate (Verity, 1981).

In the present work, salinity and temperature did not have a remarkable effect on the cellular chlorophyll- $a$ content of the four species. The highest values were found under stressed temperature-salinity conditions, when cellular division rate was inhibited. A similar behaviour was demonstrated for Platymonas sp, which exhibited maximum chlorophyll concentrations at the extremes of the salinity range (McLachlan, 1961). This author pointed out that low salinities seemed to restrict cell division although chlorophyll synthesis was not affected in the same extent.

\section{Conclusions}

The four species examined are euryhaline and eurythermic. $P$. tricomutum and $T$. gracilis showed a wider adaptability to salinity changes. In an estuarine environment, where salinity fluctuations are very large, they could have competitive advantages. $M$. polymorphus and Chaetoceros sp showed maximum growth rates in higher temperatures. When summer conditions prevail, these species could be favoured. P. tricomutum and $T$. gracilis grew better in lower temperatures. The results obtained suggest that temperature and salinity affect the distribution and abundance of phytoplankton in the marine environment.

\section{Acknowledgments}

This research is a part of a dissertation by T. C. S. Sigaud submitted in partial fulfillment to the requirements for the Master of Science degree at the Universidade de São Paulo. We wish to thank particularly to CIRM"Comissão Interministerial para os Recursos do Mar" for providing the financial support and also to FAPESP"Fundação de Amparo à Pesquisa do Estado de São Paulo" for aiding with a postgraduate fellowship (T.C.S.S.). We are grateful to C. B. de Souza, S. M. Koyama and M. Fujimura for their assistance in statistical analysis.

\section{References}

AIDAR-ARAGÃO, E. 1980. Alguns aspectos da autoecologia de Skeletonema costatum (Greville) Cleve de Cananéia $\left(25^{\circ} \mathrm{S} 48^{\circ} \mathrm{W}\right)$, com especial referência ao fator salinidade. Ph. D. Thesis, Universidade de São Paulo, Instituto Oceanográfico. 190 p.
BAARS, J. W. M. 1988a. Autecological investigations on marine diatoms. 5: Coscinodiscus concinnus W. Smith and Rhizosolenia setigera Brightwell. Hydrobiol. Bull., 22:147-155.

1988b. Autecological investigations on marine diatoms. 6: Rhizosolenia robusta Norman, Rhizosolenia imbricata Brightwell and Rhizosolenia shrubsolei Cleve. Hydrobiol. Bull., 22:157-162.

BEN-AMOTZ, A. \& GILBOA, A. 1980. Cryopreservation of marine unicellular algae. II. Induction of freezing tolerance. Mar. Ecol. Prog. Ser., 2:221-224.

BERLAND, B. R. 1966. Contribution à l'étude des cultures de diatomées marines. Recl Trav. Stn mar. Endoume, 56:5-82.

BONIN, D. J.; DROOP, M. R.; MAESTRINI, S. Y. \& BONIN, M.-C. 1986. Physiological features of six micro-algae to be used as indicators of seawater quality. Cryptogam. Algol., 7:23-83.

BRAND, L.E. 1984. The salinity tolerance of forty-six marine phytoplankton isolates. Estuar. coast. Shelf Sci., 18:543-556.

BROWN, L. M. 1982. Photosynthetic and growth responses to salinity in a marine isolate of Nannochloris bacillaris (Chlorophyceae). J. Phycol., 18:483-488.

COHEN, Z. 1986. Products from microalgae. In: Richmond, A., ed. Handbook of microalgal mass cultures. Boca Raton, CRC Press. p.421-454.

EPIFANIO, C. E.; VALENTI, C. C. \& TURK, C. L. 1981. A comparison of Phaeodactylum tricomutum and Thalassiosira pseudonana as food for the oyster, Crassostrea virginica. Aquaculture, 23:347-353.

EPPLEY, R. W. 1972. Temperature and phytoplankton growth in the sea. Fish. Bull. U.S.A., 70:1063-1085.

FABREGAS, J.; ABALDE, J.; HERRERO, C.; CABEZAS, B. \& VEIGA, M. 1984. Growth of the marine microalga Tetraselmis suecica in batch cultures with different salinities and nutrient concentrations. Aquaculture, 42:207-215.

; HERRERO, C.; ABALDE, J. \& CABEZAS, B. 1985. Growth, chlorophyll $a$ and protein of the marine microalga Isochrysis galbana in batch cultures with different salinities and high nutrient concentrations. Aquaculture, 50:1-11. 
FABREGAS, J.; HERRERO, C.; CABEZAS, B. \& ABALDE, J. 1987. Growth and biochemical variability of the marine microalga Chlorella stigmatophora in batch cultures with different salinities and nutrient gradient concentration. $\mathrm{Br}$. phycol. J., 22:269-276.

FAWLEY, M. W. 1984. Effects of light intensity and temperature interactions on growth characteristics of Phaeodactylum tricomutum (Bacillariophyceae). J. Phycol., 20:67-72.

FURNAS, M. 1978. Influence of temperature and cell size on the division rate and chemical content of the diatom Chaetoceros curvisetum Cleve.J. expl mar. Biol. Ecol., 34:97-109.

GAETA, S. A. 1985. Comparação das respostas de crescimento e fotossintese de três clones- de Phaeodactylum tricornutum Bohlin. M.Sc. Dissertation. Universidade de São Paulo, Instituto Oceanográfico. 106 p.

GESSNER, F. 1970. Temperature. In: Kinne, O. ed. Marine ecology. London, Wiley-Interscience. v.1, p.363-406.

\& SCHRAMM, W. 1971. Salinity: plants. In: Kinne, O.ed. Marine ecology. London, Wiley-Interscience. v.1, p.705-820.

GOLDMAN, J. C. 1977a. Biomass production in mass cultures of marine phytoplankton at varying temperatures. J. expl mar. Biol. Ecol., 27: 161-169.

1977b. Temperature effects on phytoplankton growth in continuous culture. Limnol. Oceanogr., 22:932-936.

\& MANN, R. 1980. Temperature-influenced variations in speciation and chemical composition of marine phytoplankton in outdoor mass cultures. J. expl mar. Biol. Ecol., 46:29-39.

\& RYTHER, J. H. 1976. Temperature-influenced species competition in mass cultures of marine phytoplankton. Biotechnol. Bisengng, 18:1125-1144.

GUILLARD, R. R. L. 1973. Division rates. In: Stein, J. R., ed. Handbook of phycological methods, culture methods and growth measurements. London, Cambridge University Press. p.289- 311.

HARGRAVES, P. E. \& GUILLARD, R.R. L. 1974. Structural and physiological observations on some small marine diatoms. Phycologia, 13:163-172.
HAYWARD, J. 1968. Studies on the growth of Phaeodactylum tricornutum (Bohlin). IV. Comparison of different isolates. J. mar. biol. Ass. U.K., 48:657-666.

HELLEBUST, J. A. 1976. Effect of salinity on photosynthesis and mannitol synthesis in the green flagellate Platymonas suecica. Can. J. Bot., 54:1735-1741.

KOZITSKAYA, V. N. 1989. Effect of illumination and temperature on algal growth: a survey. Hydrobiol. J., 25:53-67.

KRAWIEC, R. W. 1982. Autecological and clonal variability of the marine centric diatom Thalassiosina rotula (Bacillariophyceae) in response to light, temperature and salinity. Mar. Biol., 69:79-89.

McLACHLAN, J. 1961. The effect of salinity on growth and chlorophyll content in representative classes of unicellular marine algae. Can. J. Microbiol., 7:399-406.

MILLER, R. L. \& KAMYKOWSKI, D. L. 1986. Effects of temperature, salinity, irradiance and diurnal periodicity on growth and photosynthesis in the diatom Nitzschia americana: light-limited growth. J. Plankt. Res., 8:215:228.

MORRIS, I. \& GLOVER, H. E. 1974. Questions on the mechanism of temperature adaptation in marine phytoplankton. Mar. Biol., 24:147-154.

NELSON, D. J.; D'ELIA, C. F. \& GUILLARD, R. R. L. 1979. Growth and competition of the marine diatoms Phaeodactylum tricornutum and Thalassiosira pseudonana. II. Light limitation. Mar. Biol., 50:313-318.

NETER, J.; WASSERMAN, W. \& KUTNER, M. H. 1990. Applied linear statistical modelsRegression, analysis of variance and experimental designs. $3^{\text {rd }}$ ed. Homewood, R. D. Irwin. $1181 \mathrm{p}$.

OKAUCHI, M. \& FUKUSHO, K. 1984. Food value of a minute alga, Tetraselmis tetrathele, for the rotifer Brachionus plicatilis culture. I. Population growth with batch culture. Bull. natn. Res. Inst. Aquaculture, 5:13-18.

\& HIRANO, Y. 1986. Nutritional value of Tetraselmis tetrathele for larvae of Penaeus japonicus. Bull. natn. Res. Inst. Aquaculture, 9:2933.

PAASCHE, E. 1975. The influence of salinity on the growth of some plankton diatoms from brackish .water. Norw. J. Bot., 22:209-215. 
PROVASOLI, L.; McLAUGHLIN, J. J. A. \& DROOP, M. R. 1957. The development of artificial media for marine algae. Arch. Mikrobiol., 25:392-428.

RAVEN, J. A. \& GEIDER, R.J. 1988. Temperature and algal growth. New Phytol., 110:441-461.

RAYMONT, J. E. G. \& ADAMS, M. N. E. 1958. Studies on the mass culture of Phaeodactylum. Limnol. Oceanogr., 3:119-136.

REDALJE, D. G. \& LAWS, E. A. 1983. The effects of environmental factors on growth and the chemical and biochemical composition of marine diatoms. I. Light and temperature effects. J. expl mar. Biol. Ecol., 68:59-79.

RENDALL, D. A. \& WILKINSON, M. 1986. Environmental tolerance of the estuarine diatom Melosira nummuloides (Dillw.) Ag. J. expl mar. Biol. Ecol., 102:133-151.

RICHMOND, A. E. 1986. Microalgaculture. CRC Critical Rev. Biotechnol., 4(4):369-438.

SAKS, N. M., 1982. Temperature, salinity and ultraviolet irradiation effects on the growth of strains of Nitzschia ovalis. Mar. Biol., 68:175-179.

SHARP, J. H.; UNDERHILL, P. A. \& HUGHES, D. J. 1979. Interaction (allelopathy) between marine diatoms: Thalassiosira pseudonana and Phaeodactylum tricornutum. J. Phycol., 15:353-362.

SHIMURA, S.; SHIBUYA, H. \& ICHIMURA, S. 1979. Growth and photosynthesis properties of some planktonic marine diatoms at various salinity regimes. Mer, Tokyo, 17:149-155.

SHUBERT, L. E. 1984. Algae as ecological indicators. London, Academic Press. 434 p.

SPENCER, C. P. 1954. Studies on the culture of a marine diatom. J. mar. biol. Ass. U.K., 33:265-290.

STRICKLAND, J. D. H. \& PARSONS, T.R. 1968. A practical handbook of seawater analysis. Bull. Fish. Res. Bd Can., (167):1-311.

SUBBA RAO, D. V. 1981. Growth response of marine phytoplankters to selected concentrations of trace metals. Bot. mar., 24:369-379.
TEIXEIRA, C. 1973. Preliminary studies of primary production in the Ubatuba region (Lat. $23^{\circ} 30^{\prime} \mathrm{S}$ Long. 45 $\left.06^{\prime} \mathrm{W}\right)$, Brazil. Bolm Inst. oceanogr., S Paulo, 22:29-58.

TSURUTA, A.; OHGAI, M.; UENO, S. \& YAMADA, M. 1985. The effect of the chlorinity on the growth of planktonic diatom Skeletonema costatum (Greville) Cleve in vitro. Bull.japan. Soc. scient. Fish., 51:1883-1886.

VERITY, P. G. 1981. Effects of temperature, irradiance, and daylenght on the marine diatom Leptocylindrus danicus Cleve. I. Photosynthesis and cellular composition. J. expl mar. Biol. Ecol., 55:79-91.

VIEIRA, A. A. H. 1975. Estudos experimentais em fitoplâncton marinho. Culturas e aspectos ecofisiol6gicos. M.Sc. Dissertation. Universidade de Sāo Paulo, Instituto Oceanográfico. 106 p.

WALSH, D. T.; WITHSTANDLEY, C. A.; KRAUS, R. A. \& PETROVITS, E. J. 1987. Mass culture of selected marine microalgae for the nursery production of bivalve seed. J. Shellfish Res., 6:71-77.

WATRAS, C. J.; CHISHOLM, S. W. \& ANDERSON, D.M. 1982. Regulation of growth in an estuarine clone of Gonyaulax tamarensis Lebour: salinity-dependent temperature responses. J. expl mar. Biol. Ecol., 62:25-37.

WIKFORS, G. H.; TWAROG JR, J. W. \& UKELES, R. 1984. Influence of chemical composition of algal food sources on growth of juvenile oysters, Crassostrea vinginica. Biol. Bull. mar. biol. Lab., Woods Hole, 167:251-263.

YODER, J. A. 1979. Effect of temperature on light-limited growth and chemical composition of Skeletonema costatum (Bacillariophyceae). J. Phycol., 15:362-370.

(Manuscript received December 10 1992; revised July 7 1993; accepted December 17 1993) 